Przemysław ŻUKIEWICZ

DOI : $10.14746 / p p .2018 .23 .4 .3$

University of Wroclaw

ORCID ID: https://orcid.org/0000-0001-7579-4341

Mateusz ZIELIŃSKI

Social Network Hub

ORCID ID: https://orcid.org/0000-0003-1958-3683

Katarzyna DOMAGAŁA

University of Wroclaw

ORCID ID: https://orcid.org/0000-0001-9036-1050

\title{
Social Network Analysis as a research method in political science. An attempt to use it in coalition research ${ }^{1}$
}

\begin{abstract}
The main aim of the article is to argue the need for better focus of researchers conducting their research in the field of political science on some digital analytical tools used in social network analyses. Additional objectives are to outline the historical context of SNA's development in this discipline, as well as to present possible fields of exploration and using of this method, both in basic and in applied research. Particular attention was paid to the potential of SNA in the study of the processes of cabinet coalitions formation, as well as to the important limitations of this method. The article was constructed as a methodological essay. We inevitably accept - because of its focus on network analyses - a structural perspective on social reality. We verify the hypothesis that the greatest potential of SNA could be currently to create a visualization of social relations based on large data sets, but at the same time the most important barrier to the development of the method are limitations in the access to these data, which could be used as a basic analytical material for visualization of the network and generalization of the statistical conclusions. Presenting some political science research in Poland and around the world, in which SNA tools are used, we used the historical as well as the case study method.
\end{abstract}

Key words: Social Network Analysis; SNA; networks; research methods; coalition

\section{Introduction}

n the discipline of political science, the Social Network Analysis (SNA) method was not received enthusiastically. While psychologists, sociologists and economists have been actively trying to develop SNA tools and apply them to their research (Festinger, 1949; Cartwright, Harary, 1956; Radcliffe-Brown, 1952, 1957; Katz, Lazarsfeld, 1955), there are no such large-scale trials made by political scientists. Until now, in many academic textbooks devoted to research methodology in the political science discipline, there is no references to SNA as a potentially prospective and useful method of analyzing political phenomena - this applies to both Polish and English-language works (see: Johnson, Reynolds, Mycoff, 2010; Marsh, Stoker, 2006; Krauz-Mozer, Ścigaj, 2013; Antoszewski et al., 2009; Bäcker et al., 2016).

${ }^{1}$ The article is the result of research project No. 2015/19/B/HS5/00426 financed by the National Science Center. 
At the same time, within the most important world congresses and in the largest international scientific association gathering political scientists, there are active groups of researchers who share the results of their analyzes, which were carried out with the assistance of SNA tools. In 2017, a ground-breaking methodological publication - The Oxford Handbook of Political Networks (2017) - was published. It was devoted exclusively to this method and its application in political science. In the scientific journals, articles presenting the empirical results of research conducted in the network perspective are also increasingly published (Albert, Barabási 2002; Bian et al., 2014; Hoppe, Reinelt, 2010). In the effect, the SNA method itself, as well as its potential applications in the discipline of political sciences, must become the subject of a deeper theoretical and methodological reflection.

\section{Inclusion of SNA tools into the political science research - historical perspective}

It is not purposive to present - even in a sketchy form - the history of SNA development as a research method, especially since numerous considerations on this topic are included in the most important methodological textbooks that are devoted to it (Prell, 2012, pp. 19-59; Scott, 2013, pp. 11-40; Robins, 2015, pp. 17-38; Wasserman, Faust, 1998, pp. 3-21). As in the case of many research methods, their authors do not agree, where to find sources and points of breakthrough in the application of this method (Barabási, 2002, pp. 2-3). Undoubtedly, it is worth emphasizing that SNA developed autonomously in many disciplines, which is probably a consequence of a wide spectrum of its potential applications - networks can be analyzed in a biological, technological or social perspective, that is wherever dependencies can be found between the elements that make up a specific structure (see: Watts, Strogatz, 1998; Grivan, Newman, 2002; Granovetter, 1985; Salomon, Sagasti, Sachs-Jeantet, 1994).

Most often, the network perspective is associated with the achievements of political psychologists such as Paul Lazarsfeld or Bernard Berelson (see: Knoke, 1994, pp. 1-29). The work of Robert Putnam, who has highlighted and demonstrated the importance of the informal network of contacts between people involved in specific social relations (Putnam, 2008, pp. 158-195), can certainly be regarded as a kind of breakthrough. However, it is difficult to treat the efforts of individual researchers in particular sub-disciplines as a manifestation of some greater interest in the SNA method itself. Especially that in the case of the cited authors, we can talk at most about adopting a specific network perspective using other research methods (mainly statistical analyzes).

Scott D. McClurg and Joseph K. Young draw attention to the possible causes of exclusion of the political science from the relational return in broadly understood social sciences. In their opinion, important paradigms, within which researches were developed, such as behavioralism, theory of rational choice or neo-institutionalism were based on the assumption that the individual is responsible for making decisions, therefore the analysis of motivations that guide people should be made on a single actor level, and then possibly aggregated on a macro-scale. This assumption was in clear contradiction with the foundations of network research. In this perspective, it is presumed that social relations and structures 
are important predictors allowing to explain the most important phenomena of social life (McClurg, Young, 2001, pp. 39; Banaś, Zieliński, 2015, p. 33).

David Lazer lists three areas in which SNA has developed most dynamically in the United States. Firstly, the method proved to be useful in research on innovations in the field of public activities (network management, communication improvement, new methods of coordination). Secondly, it was used to explain the impact of broader social structures (family, peer group, employee group) on electoral decisions of individuals. Thirdly, it was useful in research on the influence of the individual's position in a given network (structure) on the ability of the authority and control (Lazer, 2011, p. 62; Banaś, Zieliński, 2015, pp. 33-34).

\section{Institutionalization of SNA in political sciences}

The increasing interest of political scientists in the SNA tools was accompanied by a peculiar institutionalization of research activity. Currently, the most important scientific conference bringing together SNA researchers from around the world is organized annually by the scientific association "International Network for Social Network Analysis" (INSNA), Sunbelt Conference. The association was founded in 1977 in Delaware (US) and focused on researchers seeking to develop research in the field of SNA. The founder of INSNA and its first president was Barry Wellman, considered today as one of the most important scholars for SNA (see: Wellman, 1983; Wellman, Berkowitz, 1988). B. Wellman made his scientific career at the University of Toronto, where he founded and professionalized the virtual laboratory NetLab. Despite the fact that during the conferences organized within the Sunbelt Conference series (the last took place in 2018 at the University of Utrecht) numerous results of research in the discipline of political science are presented, the formula of this event is definitely wider - SNA method remains the axis of all presentations and it is used in research of various disciplines or interdisciplinary research.

Unfortunately, SNA researchers are not represented in the scientific committees of the most important world political science organization - the International Political Science Association (IPSA). This issue is sometimes taken up by members of the Concepts and Methods Research Committee (RC01), and attention is paid to SNA at the annual conferences organized by the Political Power Research Committee (RC36).

Political researches with the use of SNA tools seem to be most dynamically pursued by researchers concentrated in two continental associations: the American Political Science Association (APSA) and the European Consortium for Political Research (ECPR). In the first of them, the research section of Political Networks operates, whose members organize the Annual Political Networks Conference and Workshops (in 2018 the 11th edition of this event took place).

Within the ECPR, also under the name Political Networks, so-called Standing Group has been established. The Standing Group on Political Networks aims to accelerate the use of perspectives and network tools to better understand the political dynamics characterizing modern societies - from social movements, through individual political behavior to the use of information and communication technologies as a tool for participation 
in political life. To achieve this goal, the Standing Group regularly organizes events and discussion panels during the ECPR General Conference, workshop sessions and methodological schools.

\section{The most important concepts of SNA applied in political science research}

First of all, one should distinguish thinking about the network structure as a defined metaphor from treating the network as a structured relation between actors, which can be visualized and measured using appropriate algorithms and parameters (Dowding, 1995). The understanding of the network in terms of metaphor can be found in these scientific and popular science papers, in which the existence of links between the consequences of actions of specific entities is indicated. Perhaps in recent years the most popular term that can be perceived as an exemplification of the metaphorisation of the network is the "network society."

Although SNA grew on the basis of observation of the social world understood as a structured form of relationship and initially this metaphor was used as an argument to develop network research, nowadays one can observe the striving to "materialize" the network in the form of determining their most important characteristics, which could - on one hand form the basis for the description of a single network, and on the other hand be a building material for comparative analyzes of many networks. The most important parameters of the network measurement are be presented below with examples from the studies of Zygmunt et al. (2009) on the blogosphere.

Networks are always sets of interconnected nodes. The connection between the nodes is defined as the edge. Visualization of the network is a type of graph (hence we can notice very frequent references to terminology taken from graph theory - see Barabási, 2016, chapter 2). Some experts in the field of SNA indicate that the assumption that the graph represents a social network is a wrong simplification (Robins, 2015, p. 18). In this case, what factors are useful in order to distinguishes a social network from a graph? First of all, the social network is made up of social actors, who are attributed to network activity, very often with motivational or strategic background. In the network, the ties between the actors can be positive or negative. Graph, on the other hand, has only nodes and edges. While these types of ties have an impact on the network's expansive capabilities, this does not have a major impact on the computing capabilities of the network itself. We can still measure various indicators (Everett, Borgatti, 2014, p. 111).

Each network can have its basic descriptive statistics. One of them is density, which is understood as a number of ties in the network as a proportion of the total number of possible ties that are present (Robins, 2015, p. 22-23). In the complete graph, there are all possible edges, then the density $=1$. When the graph is empty and has no ties, then the density $=0$. It is also worth briefly explaining degree index. In the undirected graph degree of a node is simply the number of edges emitted from it. In the directed graph there are two variations of this index. In-degree is the number of ties directed to a node, while out-degree is the number of ties directed away from it. It is also possible for each node to measure individual average degree per node. In practice, degree also correlates 
strongly with other measures, especially the measures of centrality, making it a powerful summary index (Butts, 2008, p. 21).

One of the most important categories in SNA is the already mentioned centrality of the network. It describes the position of the node in the network structure and determines its validity, significance and influence on other nodes in the network. The centrality of a node can be measured in various ways. Bary center is a measure describing a given node, calculated on the basis of all the shortest paths leading to this node from other nodes. In the study of Zygmunt et al. it was assumed that the blogger with the highest bary center index can quickly obtain information gathered in all blogs in the Internet (Zygmunt et al., 2009, p. 675). ${ }^{2}$

On the other hand, the measure of betweenness centrality (there is definitely no unified and consistent translation of the term in Polish language) is calculated on the basis of the shortest paths between particular nodes that pass through a given node (Brandes, 2001; Newman, 2005). In practice, this means that a node with a high rate of betweenness centrality has a big impact on other nodes of the network because it transmits information. In the study Zygmunt et al. it was assumed that blogs with high values of this measure can be treated as critical points of the network, the removal of which may hamper the flow of information in the network (Zygmunt et al., 2009, p. 676).

It is also worth to highlight that networks themselves may differ from each other and therefore researchers using SNA tools often distinguish binary networks (attention is paid only to the fact that there is a connection between nodes, but this connection is not characterized) and weighted networks (connections can have different weights, reflecting different levels of intensity of interaction). Taking into account the criterion of direct targeting in a network, it is also possible to distinguish directed networks (connections between nodes have a direction designated usually by arrowheads) and undirected networks (links have no direction) (Jarynowski, Boland, 2013, p. 36).

There are also networks in which one can specify hubs, or nodes getting a visibly higher than average number of connections. Such an important type of network is called a complex network - a concept that was developed by Albert-László Barabási and Réka Albert (2002).

The research procedures of SNA depend strongly on a complete database of relations between entities that form a network of mutual relations. Each such relationship should be coded by assigning appropriate values to it, which can then be used for visualization or statistical analysis (Prell, 2012, pp. 68-87). The prescribed value depends, however, on the subject of the study. Different attributes of connections will be taken in to considerations in analysis concerning social media (media science), different in networks reflecting flow of goods (logistics), and different in research on coalition negotiations (political science).

2 This is an example that has a great didactic value, because it shows what is actually being researched using SNA tools and what benefits it can bring. The authors pay attention to: a) blogosphere modeling, thanks to which one can better understand the structure and properties of the blogosphere: dependencies between bloggers, blog posts or various types of blogs; b) clustering of blogs, i.e. automatic linking of blogs (e.g. based on tags describing blogs) in similar groups to facilitate browsing the blogosphere; c) identification of influential bloggers that can influence the sale or promotion of the brand (Zygmunt et al., 2009, p. 674). 
Researchers, visualizing networks and distinguishing their the most important attributes, use a software available either under a free license or commercially provided by various companies. The most popular tools include UCINET, Siena, Pajek (see Fig. 1) and Pnet. An increasing number of researchers deciding to use the R programming environment (Luke, 2015; Kolaczyk, Csárdi, 2014), which makes the SNA method even more demanding - in addition to knowledge concerning a subject of studies, some programming skills or knowledge how to create a large databases and manage it are also required.

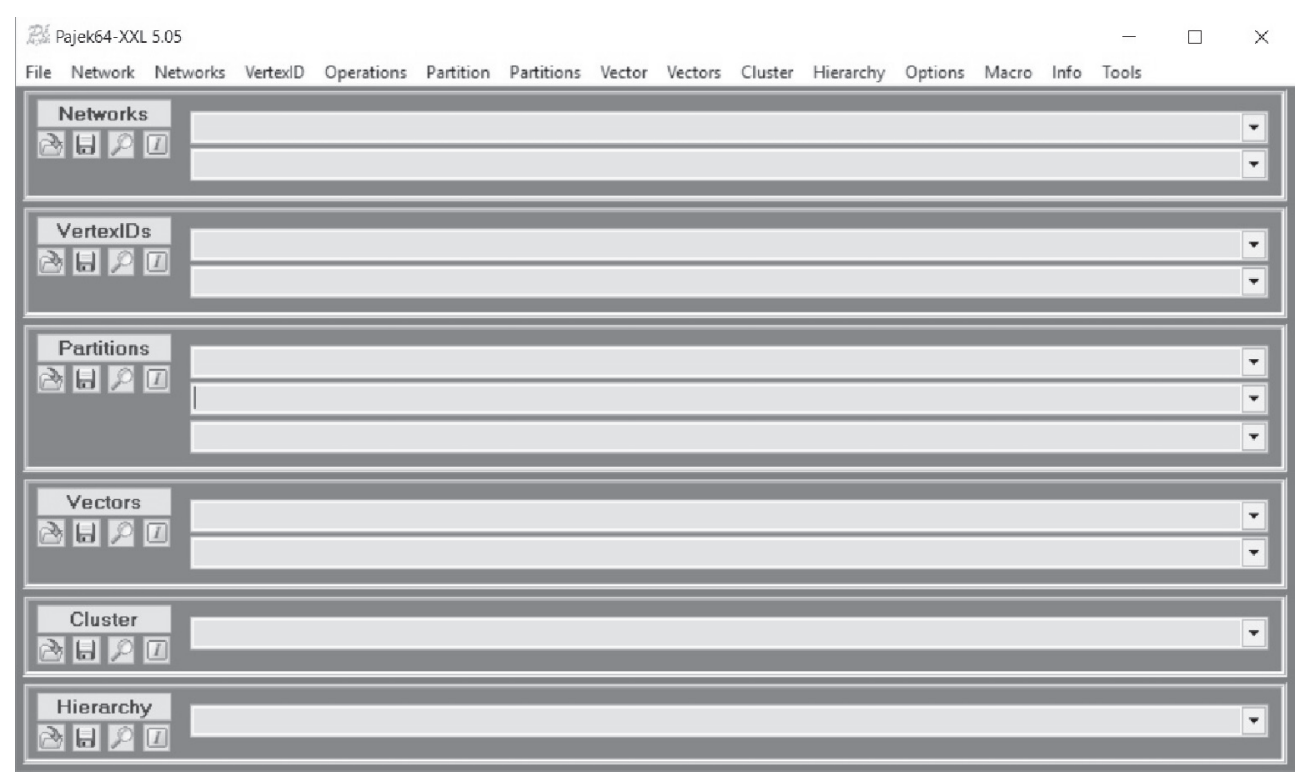

Fig. 1. The control panel for Pajek - a free software tool for SNA

Source: Print screen - authors own elaboration. Pajek can be downloaded from: http://mrvar.fdv.uni-lj.si/ pajek/.

\section{Possible applications of SNA in the discipline of political science}

In the discipline of political sciences the fields of exploration where the SNA tools are applicable are practically boundless. The only barrier that might appear in this context is a limited access to data. Precise data set is indispensable to create a network's visualization and take measurements of its most important parameters.

However, there are several areas where SNA applications contribute to the study of political networks in the most substantial manner. The first one - probably the easiest to link with SNA - is the new sphere of interference between social media and politics. The number of analysis on building and maintaining relationships emerging on Facebook or Twitter, between non-institutionalized users and professional broadcasters, such as parties, governments, media, electoral staffs, have burst up after Barrack Obama 2008 presidential campaign. The researchers, however, are going nowadays far beyond well- 
examined elections in United States. Kokil Jaidka, Saifuddin Ahmed and Marko Skoric using comparative studies on three different Asian countries (Malaysia, India, and Pakistan) tried even to prove - with a quite convincing effect - that is possible to predict the final outcome of a general elections basing on "sentiment analysis" combined with SNA (Jaidka et al., 2018).

The use of SNA in electoral studies are not limited although to the changing dynamics in candidate-voter relations introduced by the advent of the Web 2.0. Another area where SNA is applied successfully are studies on intra-party relationships and networks of their cooperation with external entities. In such studies Suzanne M. Robbins uses network tools to analyze cash-flow among donors supporting two main political parties in USA through the system of highly criticized by her "political action committees" (Robbins, 2010).

The discussed method is also applicable to studies on beneficiaries of social assistance, sustainable transport, education policy and other types of public policies. Studies of Frédéric Varone, Karin Ingold and Manuel Fischer proved, with a help of SNA, how public administrative entities can become more flexible, adopting different functions in a policy network (such as a "network facilitator," "policy broker" or "mediator in social conflicts") when abandoning a state-centric vision and strictly hierarchical models (Varone, Ingold, Fischer, 2018).

SNA is also an increasingly relevant research method in the field of international relations studies. Analysis concerning global trade, diplomatic contacts and - in a broader sense - relations between states and international organizations occurred to be perfectly fitted to SNA application. With such intention, Emilie M. Hafner-Burton, Miles Kahler and Alexander H. Montgomery use SNA, putting in a question a conventional view on power in international relations. Using a toolkit related to network studies they asses the ability of different kind of actors to increase their power by exploiting their position in networks in different models of cross-border cooperation (Hafner-Burton, Kahler, Montgomery, 2009).

Similar analysis are conducted also in the area of security studies, bringing to the front the problem of functioning of organized crime networks, in particular - terrorist groups. The study of David Bright, Chad Whelan and Shandon Harris-Hogan successively employ SNA to indicate how seemingly distinct jihadists groups working in the Western countries coordinate their actions through the actions of network brokers and how such groups thanks to network-like structures achieve long lasting durability (Bright, Whelan, Harris-Hogan, 2018).

Finally, SNA is also used for self-analysis of particular scientific disciplines. By means of this method, researchers analyze patterns of cooperation between scientists, related to an implementation of joint researches or publication projects. The network beyond shows the results of the research of German scientists, indicating the most important clusters of cooperation and researchers with the highest centrality and prestige.

The opportunities and barriers related to SNA method might be well illustrated by the attempt to apply this method to the analysis of cabinet coalition formation processes. The use of SNA in this field seems to be responding correctly to some primary expectations of scientists - negotiation processes have always a relational nature and are based on interaction between at least two political entities (actors-nodes). An additional advantage 


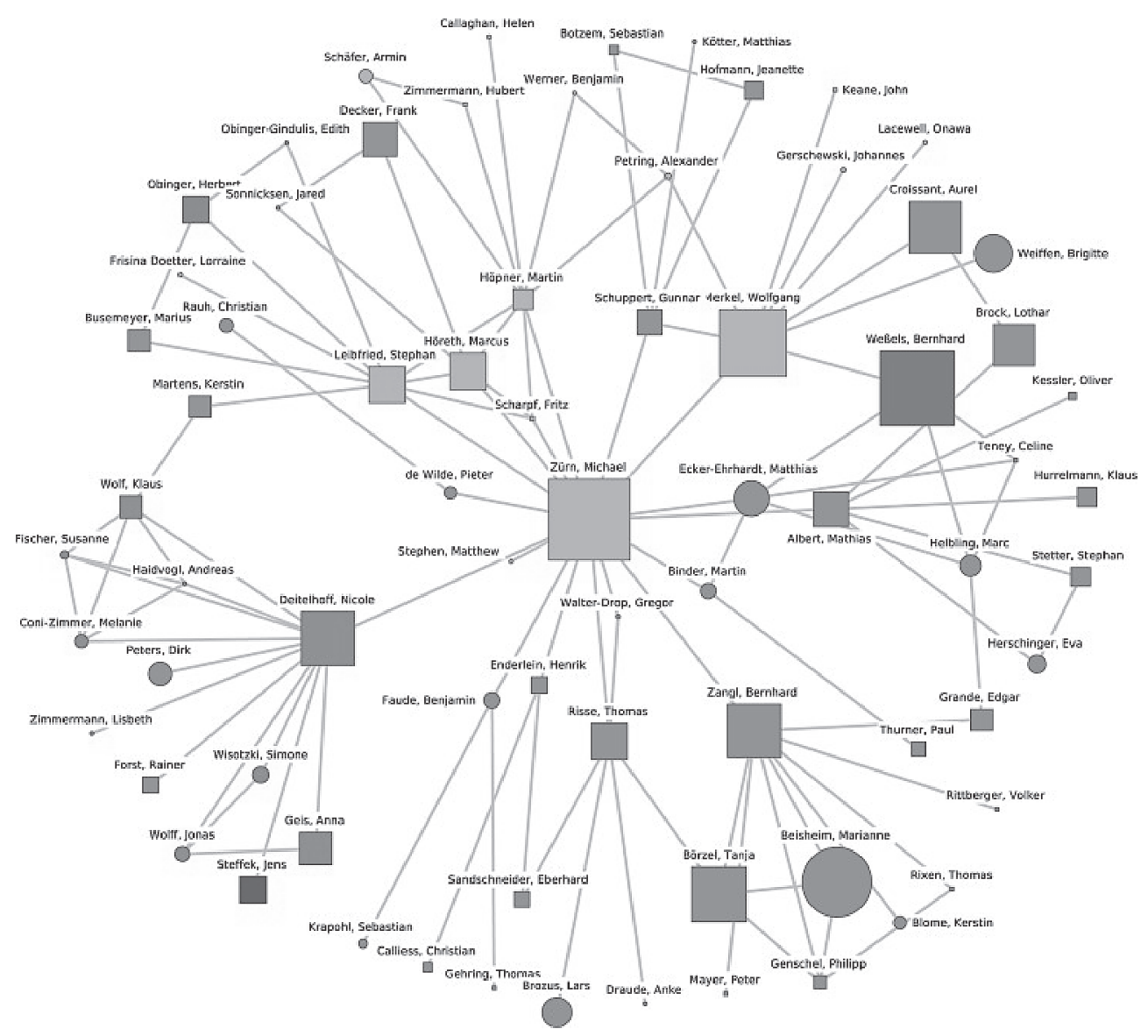

Fig. 2. Network's cluster of publishing cooperation among German political scientists ${ }^{3}$

Source: Leifeld P. et al. (2017).

of SNA could be also its focus on links between particular individual actors instead of entire organizations. This is important especially when political parties are not perceived as monolithic entities. However, it is puzzling in this context that the review of world literature does not provide a vast number of SNA analyzes regarding cabinet coalitions. Michał Banaś and Mateusz Zieliński tried to fill this research gap in Poland by examining the process of creating a PO-PSL coalition in 2007 with the SNA (Banaś, Zieliński, 2015).

Despite the fact that the authors managed to confirm some very important conclusions (including the existence of internal divisions in political parties, the crucial role of the party leaders in the negotiation process, the influence of external actors on the coalition formation process, a key character of actors' communication skills in the process of maintaining relations and the multi-aspect nature of the coalition formation process), they

${ }^{3}$ Centrality does not mean that people at the center of the network publish the most (or most efficiently), but that they are important from the point of view of the relationship between network actors. 
concluded by stressing that the application of SNA to research on the coalition formation process faces many problems. The most important included the lack of information on negotiations conducted in a narrow circle of negotiators who are usually not willing to provide a reliable insight into the process, and the inability to avoid subjective opinions of journalists describing the coalition's process (Banaś, Zieliński, 2015, p. 126).

A methodological proposal that could enable the use of SNA tools for research into coalition formation processes may be the separation of different networks depicting ontically differentiated relations (Żukiewicz, Domagała, Zieliński, 2017). One can distinguish her three different networks:

1) networks of direct and confirmed meetings between political (direct actor-to-actor connections);

2) network of mediated by media contacts between political actors (mediated actor-toactor connections);

3) network of media-speculated contacts between political actors (supposed actor-toactor connections).

Such a solution requires application of additional tools such as a semantic analysis that allows to a researcher to extract more specific connections from a database and assign to them certain values (semantic network analysis - see Atteveldt, 2008). There is no doubt, however, that the media remains the only "provider" of data in the event of coalition negotiations. Direct actors are rarely willing to participate in the survey, providing in-depth interviews or completing a questionnaire.

Reliable reconstruction of network relations must, therefore, take into account the diverse status of media coverage - different meaning (and scientific value) will have media coverage of direct meetings between political actors, different media release about coalition preferences of certain politicians, and still different opinions of journalists, experts and other non-participating in direct negotiations actors regarding parties' potential coalition strategies. Although all three levels of analysis jointly create a specific "climate" of talks on the creation of a coalition, their precise methodical separation may allow to indicate which actors had the greatest impact on the real negotiations, and who held a central position in the coalition media discourse, although not participating in the negotiations. The comparison of statistical parameters of individual networks may therefore provide additional arguments and evidence for hypothesis about the importance of the media in the process of making the most important political decisions, and thus enrich the classic theories of coalition formation with an absent (till now) media component.

\section{Conclusions}

One can agree with Sławomir Kotylak, who notes that "SNA from conventional social research tools is distinguished by the fact that the focus of this method lies in the so-called relational data, not attributes. In the case of social network research, it is cooperation or communication on substantive issues that indicates the actual role of a given unit (or group of people) as part of the process of creating and accessing information" (Kotylak, 2011, pp. 165-166). The potential use of the SNA method seemed to be unnoticed until recently in the discipline of political sciences. Nevertheless, the development 
of information technologies, widespread acceptance of the importance of "networking" in the cross-linked global society and the activity of the most important researchers developing the SNA are slowly changing this situation. The SNA is becoming a well accepted research method, and the most important political research associations create sections in which scientists exchange their experiences.

Analysis of the literature on the subject indicates that SNA is - and probably will be - applied in numerous research fields. Particularly strongly marks its presence in analyzes carried out on large data sets (big data), mainly because it gives a simplified view of the complex network structure of the studied phenomena and their relational nature. At the same time, relying on the researchers abilities to collect such data may be the biggest barrier and obstacle in the development of the method: it will remain unusable where access to the data is limited or impossible to reach.

\section{Bibliography}

Albert R., Barabási A. L. (2002), Statistical mechanics of complex networks, "Reviews of Modern Physics," vol. 74, pp. 47-97.

Atteveldt W. van (2008), Semantic network analysis: techniques for extracting, representing and querying media content, Charleston.

Bäcker R. et al. (2016), Metodologia badań politologicznych, Warszawa.

Banaś M., Zieliński M. (2015), Formowanie koalicji gabinetowych w perspektywie sieciowej Studium przypadku sojuszu PO-PSL z 2007 roku, Wrocław.

Barabási A.-L. (2016), Network science, Cambridge.

Barabási A.-L. (2003). Linked: The new science of networks, New York.

Bian J., Xie M., Hudson T. J., Eswaran H., Brochhausen M., Hanna J., Hogan W. R. (2014), CollaborationViz: Interactive Visual Exploration of Biomedical Research Collaboration Networks, "PLoS ONE," vol. 9, no. 11.

Brandes U. (2001), A faster algorithm for betweenness centrality, "Journal of Mathematical Sociology," vol. 25, no. 2, pp. 163-177.

Bright D., Whelan Ch., Harris-Hogan Sh. (2018), On the Durability of Terrorist Networks: Revealing the Hidden Connections between Jihadist Cells, "Studies in Conflict \& Terrorism," pp. 1-19, DOI: 10.1080/1057610X.2018.1494411.

Butts T. C. (2008), Social network analysis: A methodological introduction, “Asian Journal of Social Psychology," no. 11, pp. 13-41.

Cartwright D., Harary F. (1956), Structural balance: A generalization of Heider's theory, "Psychological Review," no. 63, pp. 277-292.

Dowding K. (1995), Model or Metaphor? A Critical Review of the Policy Network Approach, "Political Studies," vol. 43, no. 1, pp. 136-158.

Everett M. G., Borgatti S. P. (2014), Networks containing negative ties, "Social Networks," no. 38, pp. 111-120.

Festinger L. (1949), The analysis of sociograms using matrix algebra, "Human Relations," vol. 2, pp. 153-158.

Girvan M., Newman M. E. J. (2002), Community structure in social and biological networks, "Proceedings of the National Academy of Sciences," vol. 99, no. 12, pp. 7821-7826.

Granovetter M. (1985), Economic Action and Social Structure: The Problem of Embeddedness, "American Journal of Sociology,” vol. 91, no. 3, pp. 481-510. 
Hafner-Burton E. M., Kahler M., Montgomery A. H. (2009), Network Analysis for International Relations, "International Organization," vol. 63, no. 3, pp. 559-592.

Hoppe B., Reinelt C. (2010), Social network analysis and the evaluation of leadership networks, "The Leadership Quarterly," vol. 21, pp. 600-619.

Jaidka K., Saifuddin A., Skoric M., Hilbert M. (2018), Predicting Elections from Social Media: A ThreeCountry, Three-Method Comparative Study, „Asian Journal of Communication,” pp. 1-21, DOI: 10.1080/01292986.2018.1453849.

Jarynowski A., Boland S. (2013), Rola analizy sieci spolecznych w odkrywaniu narracyjnej struktury fikcji literackiej, „Biuletyn Instytutu Systemów Informatycznych,” vol. 12, pp. 35-42.

Johnson J. B., Reynolds H. T., Mycoff J. D. (2010), Metody badawcze w naukach politycznych, Warszawa.

Katz E., Lazarsfeld P. F. (1955), Personal Influence: The Part Played by People in the Flow of Mass Communication, Glencoe.

Knoke D. (1994), Political Networks: The Structural Perspective, Cambridge.

Kolaczyk E. D., Csárdi G. (2014), Statistical Analysis of Network Data with R, New York.

Kotylak S. (2011), Analiza sieci społecznych (SNA) jako narzędzie audytu rozwoju komunikacji społeczeństwa informacyjnego, „Ekonomiczne Problemy Usług,” vol. 67, pp. 161-168.

Lazer D. (2011), Networks in Political Science: Back to the Future, "PS: Political Science \& Politics," vol. 44, no. 1, pp. 61-68.

Leifeld P., Wankmüller S., Berger V. T. Z., Ingold K., Steiner C. (2017), Collaboration patterns in the German political science co-authorship network, "PLOS ONE," vol. 12, no. 4, e0174671, https://doi.org/10.1371/journal.pone.0174671.

Luke D. A. (2015), A User's Guide to Network Analysis in R, New York.

McClurg S., Young J. (2011), Editors' Introduction: A Relational Political Science, "PS: Political Science and Politics," vol. 44, no. 1, pp. 39-43.

Newman M. E. J. (2005), A measure of betweenness centrality based on random walks, "Social Networks," vol. 27, no. 1, pp. 39-54.

Podejścia badawcze i metodologie w nauce o polityce (2013), eds. B. Krauz-Mozer, P. Ścigaj, Kraków.

Prell Ch. (2012), Social Network Analysis. History, theory \& methodology, London.

Putnam R. (2008), Samotna gra w kregle, Warszawa.

Radcliffe-Brown A. R. (1952), Structure and Function in Primitive Society. Essays and Adresses, London.

Radcliffe-Brown A. R. (1957), A Natural Science of Society, Glencoe.

Robins G. (2015), Doing Social Network Research, Los Angeles.

Robbins S. M. (2010), Cash Flows: Leadership PACs in the U. S. Congress from 1992-2008, "2010 43rd Hawaii International Conference on System Sciences", pp. 1-10, DOI: 10.1109/ HICSS.2010.96.

Salomon J.-J., Sagasti F. R., Sachs-Jeantet C. (1994), The uncertain quest: science, technology, and development, Tokyo-New York-Paris.

Scott J. (2013), Social Network Analysis ( $3^{\text {rd }}$ ed.), Los Angeles.

Teoretyczne i metodologiczne wyzwania badań politologicznych w Polsce (2009), eds. A. Antoszewski, A. Dumała, B. Krauz-Mozer, K. Radzik, Lublin.

Teorie i metody w naukach politycznych (2006), eds. D. Marsh, G. Stoker, Warszawa.

The Oxford Handbook of Political Networks (2017), eds. J. N. Victor, A. H. Montgomery, M. Lubell, Oxford.

Varone F., Ingold K., Fischer M. (2018), Policy Networks and the Roles of Public Administrations, in: Swiss Public Administration, eds. A. Ladner, N. Soguel, Y. Emery, S. Weerts, S. Nahrath, pp. 339-353, Cham. 
Wasserman S., Faust K. (1994), Social network analysis: methods and applications, Cambridge-New York.

Wellman B. (1983), Network analysis: Some basic principles, "Sociological Theory," vol. 1, no. 1, pp. 155-200.

Wellman B., Berkowitz S. (1988), Social structures: a network approach, New York.

Zygmunt A., Koźlak J., Krupczak Ł., Małocha B. (2009), Analiza blogów internetowych przy użyciu metod sieci społecznych, „Automatyka,” vol. 13, no. 2, pp. 673-681.

Żukiewicz P., Domagała K., Zieliński M. (2017), Coalition Formation Process in the Network Perspective: The Canadian Case, paper presented at the Annual Conference of the New Zealand Political Studies Association, 30.11.2017, Dunedin.

\section{Social Network Analysis jako metoda badawcza w dyscyplinie nauk o polityce. Próba adaptacji do badań nad koalicjami}

\section{Streszczenie}

Celem głównym artykułu jest uzasadnienie konieczności większego zainteresowania badaczy prowadzących swoje badania w dyscyplinie nauk o polityce narzędziami analitycznymi (w tym cyfrowymi) stosowanymi w ramach społecznej analizy sieciowej. Celami dodatkowymi pozostają nakreślenie kontekstu rozwoju SNA w tej dyscyplinie, a także ukazanie możliwych pól eksploracji i wykorzystania metody, zarówno w badaniach podstawowych, jak i w badaniach stosowanych. Szczególną uwagę zwrócono na potencjał SNA w badaniu procesów formowania koalicji gabinetowych, wskazując jednocześnie na ważne ograniczenia tej metody. Artykuł ma charakter metodologiczny i przyjmuję w nim - w sposób nieunikniony, jeśli rzecz ma dotyczyć analiz sieciowych - strukturalną perspektywę oglądu rzeczywistości społecznej. Weryfikuję hipotezę zakładającą, że największym potencjałem SNA jest obecnie możliwość generowania wizualizacji relacji społecznych w oparciu o duże zbiory danych (big data), jednocześnie jednak najistotniejszą barierę rozwoju metody stanowią ograniczenia w dostępie naukowców do tych danych, które mogłyby posłużyć jako bazowy materiał analityczny do wizualizacji sieci i generowania wniosków natury statystycznej. Prezentując stan badań politologicznych w Polsce i na świecie, w których wykorzystuje się narzędzia SNA, pomocniczo wykorzystuję metodę historyczną oraz metodę studium przypadku.

Słowa kluczowe: społeczna analiza sieciowa, sieć, metodologia nauk o polityce, koalicje 